\title{
Preparation and Properties of
}

\section{Thyroxine-Binding Alpha Globulin (TBG)}

\author{
Kenneth Sterling, Satoshi Hamada, Yoshihiro Takemura, \\ Milton A. Brenner, Edward S. Newman, and Mitsuo Inada \\ From the Protein Research Laboratory, Bronx Veterans Administration Hospital, \\ Bronx, New York 10468 and the Department of Pathology, Columbia University \\ College of Physicians and Surgeons, New York 10032
}

A в S T R A C T Thyroxine-binding alpha globulin (TBG) in human serum was isolated from Cohn fractions IV5,6 and IV-4 by (1) chromatography on carboxymethyl (CM) cellulose, (2) gel filtration on Sephadex G-200, (3) chromatography on diethylaminoethyl-Sephadex, (4) a novel procedure of "double-gel" electrophoresis, and (5) preparative polyacrylamide gel electrophoresis. The protein was homogeneous by analytical disc gel electrophoresis, immunoelectrophoresis, and ultracentrifugal analyses (sedimentation velocity and sedimentation equilibrium), and after addition of thyroxine ${ }^{-25} \mathrm{I}$ showed a constant specific radioactivity on polyacrylamide electrophoresis. The sedimentation and diffusion coefficients were $s_{20, w}, 3.0 \times 10^{-13} \mathrm{sec}$, and $\mathrm{D}_{20, w}, 8.05 \times$ $10^{-7} \mathrm{~cm}^{2} \cdot \mathrm{sec}^{-1}$, and the molecular weight obtained by sedimentation equilibrium was 36,500 . Gel filtration studies on Sephadex G-200 demonstrated that the protein had the same elution volume as that of native TBG in serum, apparently excluding the possibility of a subunit of the native protein. Chemical composition was ascertained by amino acid and carbohydrate analyses. The maximal thyroxine (T4)-binding capacity measured by reverse flow paper electrophoresis was $15,000 \mu \mathrm{g}$ per $\mathrm{g}$ of protein, representing more than 2100 times that of the starting material, or about 5000 times that of whole serum. Based on the molecular weight obtained, the TBG preparation could bind 0.7 mole $\mathrm{T} 4$ per mole of protein, suggesting a single binding site. The association constant for T4 was estimated to be of the order of $10^{10}$ by competitive binding studies employing TBG and T4-binding prealbumin (TBPA).

Received for publication 30 November 1970 and in revised form 2 February 1971.

\section{INTRODUCTION}

Thyroxine-binding alpha globulin $(\mathrm{TBG})^{1}$ is the major carrier of thyroid hormone among the three protein carriers (TBG, thyroxine-binding prealbumin, and albumin) in human serum, yet its concentration would appear to be less than $2 \mathrm{mg}$ per $100 \mathrm{ml}$ (1). Recent studies have demonstrated by immunoprecipitation (2) and electrophoresis $(3,4)$, that this protein binds approximately $75 \%$ of thyroxine (T4) in normal serum, indicating a more important role in $\mathrm{T} 4$ transport than previously assumed. To investigate the physical and chemical characteristics of the protein, TBG was purified to a homogeneous state.

A few previous reports (5-9) described purification of this protein from human serum, employing anion exchange chromatography and electrophoresis at alkaline $\mathrm{pH}$. In the present study, however, further purification has been achieved by new procedures which utilized the isoelectric point of approximately $\mathrm{pH} \mathrm{4}$, possessed by TBG (10).

The final preparations satisfied many criteria for homogeneity so that investigation of the molecular characteristics of the protein could be carried out.

\section{EXPERIMENTAL PROCEDURE}

\section{Materials}

Cohn fractions IV and IV-5,6 of human serum were kindly supplied by Mr. L. H. Larsen, Senior Chemist, Department of Public Health, State Laboratory Institute, Boston, Mass. The human serum albumin was Squibb's lot 2077, obtained through the Red Cross. After purification by preparative polyacrylamide electrophoresis the albumin was

\footnotetext{
${ }^{1}$ Abbreviations used in this paper: BEI, butanol extractable iodine; CM, carboxymethyl; $\mathrm{T} 3$, triiodothyronine; T4, thyroxine; TBG, thyroxine-binding alpha globulin; TBPA, T4-binding prealbumin; TEMED, tetramethylethylenedia-
} mine. 
shown to be free of TBG on reverse flow paper electrophoresis.

Solutions of ${ }^{125} \mathrm{I}$-labeled and ${ }^{131} \mathrm{I}$-labeled L-thyroxine in $50 \%$ propylene glycol with $0.2 \%$ cysteine were purchased from Abbott Laboratories, North Chicago, Ill. The extent of radioactive contamination was assessed by descending paper chromatography (11) and most labeled T4 shipments contained less than $2 \%$ triiodothyronine (T3) and less than $5 \%$ iodide. Nonradioactive sodium L-thyroxine pentahydrate with measured water content was obtained from Mann Research Laboratories, Inc., New York. The stable T4 contained approximately $0.5 \% \cdot \mathrm{T} 3$ by displacement analyses and double label studies $(11,12)$.

Carboxymethyl (CM)-cellulose (Whatman CM 11, capacity $0.6 \mathrm{mEq} / \mathrm{g}$ ) was obtained from Reeve Angel \& Co. Inc., Clifton, N. J., and Sephadex G-200 and DEAE-Sephadex A-50 (capacity, $3.5 \mathrm{mEq} / \mathrm{g}$ ) were purchased from Pharmacia Fine Chemicals, Inc., Piscataway, N. J. Acrylamide and bisacrylamide $\left(N, N^{\prime}\right.$-methylene bis acrylamide) were obtained from Eastman Organic Chemicals, Inc., Rochester, N. Y. and recrystallized from acetone before use. All solutions were made with deionized water. The various chemicals used were reagent-grade materials purchased from chemical suppliers.

\section{Methods}

Powdered fraction IV-5, 6 was dissolved at $5 \mathrm{~g}$ per $100 \mathrm{ml}$

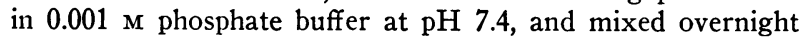
at $4^{\circ} \mathrm{C}$. The supernatant, separated by centrifugation, was dialyzed against $0.075 \mathrm{M}$ acetate buffer at $\mathrm{pH} 5.0$, and the precipitate discarded. Fraction IV-4 was prepared from fraction IV by Cohn's method as summarized by Hughes (13). The fraction obtained was used after multiple dialyses against large volumes of the acetate buffer. Maximal T4binding capacities of these starting materials, determined as described below, were $4.8-8.9 \mu \mathrm{g}$ per $\mathrm{g}$ protein as compared with $3 \mu \mathrm{g}$ per $\mathrm{g}$ of serum protein. Protein concentrations were determined by absorbance at $280 \mathrm{~m} \mu$ employing an extinction coefficient obtained as described below. All the purification procedures were carried out at $4^{\circ} \mathrm{C}$.

Carboxymethyl (CM)-cellulose chromatography. The $\mathrm{CM}$-cellulose was treated initially (or reactivated after each use) by a batch method employing successive washes of $0.5 \mathrm{M} \mathrm{NaOH}, 95 \%$ ethanol, $0.5 \mathrm{M} \mathrm{HCl}$, and $0.3 \mathrm{M}$ sodium acetate at $\mathrm{pH} 5.0$, followed by suspension in the starting buffer, $0.075 \mathrm{~m}$ acetate at $\mathrm{pH}$ 5.0. The cellulose, suspended in the acidic acetate starting buffer, was packed by gravity in a $4.5 \times 65 \mathrm{~cm}$ cold water-jacketed column, and equilibrated with 2 liters of the buffer just before use. $70-100 \mathrm{ml}$ of fraction IV $-5,6$ or IV-4 solutions (2.7-4.6 $\mathrm{g}$ of protein, enriched with a tracer amount of T4- ${ }^{125} \mathrm{I}$, usually $4-5 \mathrm{ng}$ ) was applied to the column, and eluted with 1.5 liters of the starting buffer. The effluent was collected in $15-\mathrm{ml}$ fractions. After this "overflow" chromatography, the column was washed with 2 liters of $0.3 \mathrm{~m}$ sodium acetate buffer at $\mathrm{pH} 5.0$ to elute the remaining proteins which were discarded, after which the CM-cellulose was washed for further use.

Gel filtration on Sephadex G-200. Sephadex G-200 columns were prepared by Porath's method described in reference 14. After removal of fine particles by decantation, the gel was suspended in $0.05 \mathrm{M} \mathrm{NaCl}$ solution, and packed by gravity with $15-17 \mathrm{~cm}$ of hydrostatic pressure in a Sephadex ${ }^{\circledR}$ column (Pharmacia Fine Chemicals, type K 25/100) of $2.5 \times 100 \mathrm{~cm}$ equipped with an upward flow adapter. After settling of the gel bed (height of gel column $90 \mathrm{~cm}$ ) and washing with about 1 liter of $0.05 \mathrm{M} \mathrm{NaCl}$ solution, the flow was switched to an upward direction, utilizing a peristaltic pump at a flow of $9-12 \mathrm{ml}$ per hr. The gel column was washed with 5 bed volumes of $0.05 \mathrm{M} \mathrm{NaCl}$ solution, and its efficiency for protein separation was tested by the elution pattern of applied human serum. Pooled and concentrated peaks from 5 to $15 \mathrm{CM}$-cellulose columns were combined in a volume of $10-15 \mathrm{ml}(2-3 \mathrm{~g}$ per $100 \mathrm{ml})$ and applied to the Sephadex column. The eluate was collected in 3-ml fractions.

Diethylaminoethyl (DEAE)-Sephadex chromatography. DEAE-Sephadex (A-50) was prepared according to the manufacturer's instructions. The gel freed from fine particles was suspended in $0.10 \mathrm{M} \mathrm{NaCl}-0.05 \mathrm{M}$ Tris- $\mathrm{HCl}$ at $\mathrm{pH} 8.0$ (starting buffer) and degassed. The gel was packed by gravity in a Sephadex ${ }^{\circledR}$ column of $2.5 \times 45 \mathrm{~cm}$ (Pharmacia, type $\mathrm{K} 25 / 45$ ), followed by washing with 5 bed volumes of the starting buffer. After dialysis against the starting buffer, $300-400 \mathrm{mg}$ of protein from the previous step was applied to the column and eluted by means of a linear chloride gradient established by connecting two open cylindrical liter bottles, one a magnetically stirred mixing chamber containing $800 \mathrm{ml}$ of starting buffer and the other a reservoir cylinder with $800 \mathrm{ml}$ of $0.18 \mathrm{M} \mathrm{NaCl}-0.05 \mathrm{M}$ Tris- $\mathrm{HCl}$ at $\mathrm{pH} 8.0$ (limit buffer). The rate of flow was $30-40 \mathrm{ml}$ per $\mathrm{hr}$, and the effluent was collected in $10 \mathrm{ml}$ fractions.

In some instances a second DEA-Sephadex A-50 step was carried out after "double gel" electrophoresis (below). For the second chromatography, a Sephadex ${ }^{\circledR}$ column of $1.5 \times$ $30 \mathrm{~cm}$ (Pharmacia, type $\mathrm{K} 15 / 30$ ) was used with two open $300-\mathrm{ml}$ cylindrical bottles containing $200 \mathrm{ml}$ of the starting and limit buffers. The gel was packed to a height of $25 \mathrm{~cm}$ and equilibrated with starting buffer. The flow rate was $10-12 \mathrm{ml}$ per $\mathrm{hr}$, and $3-\mathrm{ml}$ fractions were collected.

"Double gel" electrophoresis. A polyacrylamide gel electrophoresis with acid and alkaline $\mathrm{pH}$ gel layers was devised for separation of TBG. A schema of this procedure is shown in Fig. 1. A Poly-Prep ${ }^{\circledR}$ apparatus (Buchler Instruments, Inc., Fort Lee, N. J.) was used for this procedure. The upper gel was composed of $30 \mathrm{ml}$ of $7.5 \%$ acrylamide- $0.25 \%$ bisacrylamide in $0.44 \mathrm{M}$ beta alanine- $\mathrm{HCl}, \mathrm{pH} 4.0$ containing $0.14 \%$ ammonium persulfate and $0.2 \mathrm{ml}$ tetramethylethylenediamine (TEMED). The lower gel was $40 \mathrm{ml}$ of $7.5 \%$ acrylamide- $0.25 \%$ bisacrylamide in $0.15 \mathrm{M}$ Tris- $0.003 \mathrm{M}$ barbital- $\mathrm{HCl}, \mathrm{pH} 8.6$ containing $0.07 \%$ ammonium persulfate and $0.0184 \mathrm{ml}$ of TEMED. In the first electrophoresis the following buffers were used: $0.035 \mathrm{M}$ beta alanine- $0.014 \mathrm{M}$ acetic acid at $\mathrm{pH} 4.5$ (upper electrode buffer); $0.35 \mathrm{M}$ beta alanine- $0.05 \mathrm{M} \mathrm{HCl}$ at $\mathrm{pH} 4.5$ (membrane holder buffer); $1: 3$ dilution of the membrane holder buffer (elution and lower electrode buffer). In the second electrophoresis the following buffers were employed: $0.03 \mathrm{M}$ barbital- $0.0083 \mathrm{M}$ Tris at $\mathrm{pH} 7.4$ (upper electrode buffer); $0.05 \mathrm{~m}$ Tris- $\mathrm{HCl}$ at $\mathrm{pH} 8.1$ (elution and lower electrode buffer). The same buffers were employed as membrane holder buffer and lower electrode buffer throughout the two steps of the procedure; only the upper electrode and elution buffers were replaced (vide infra). Protein solution not exceeding $100 \mathrm{mg}$ in $5 \mathrm{ml}$ of the upper electrode buffer containing $3 \%$ sucrose was applied on the upper gel through a layering capillary. The first electrophoresis was performed at $24 \mathrm{ma}$ constant current for the first $30 \mathrm{~min}$, at $60 \mathrm{ma}$ constant current for the next $30 \mathrm{~min}$, and then at $800 \mathrm{v}$ constant voltage for $75 \mathrm{~min}$.

After the electrophoresis, the first upper electrode buffer was removed by aspiration, and the upper surface of the acid gel and buffer reservoir were washed once with 1.5 


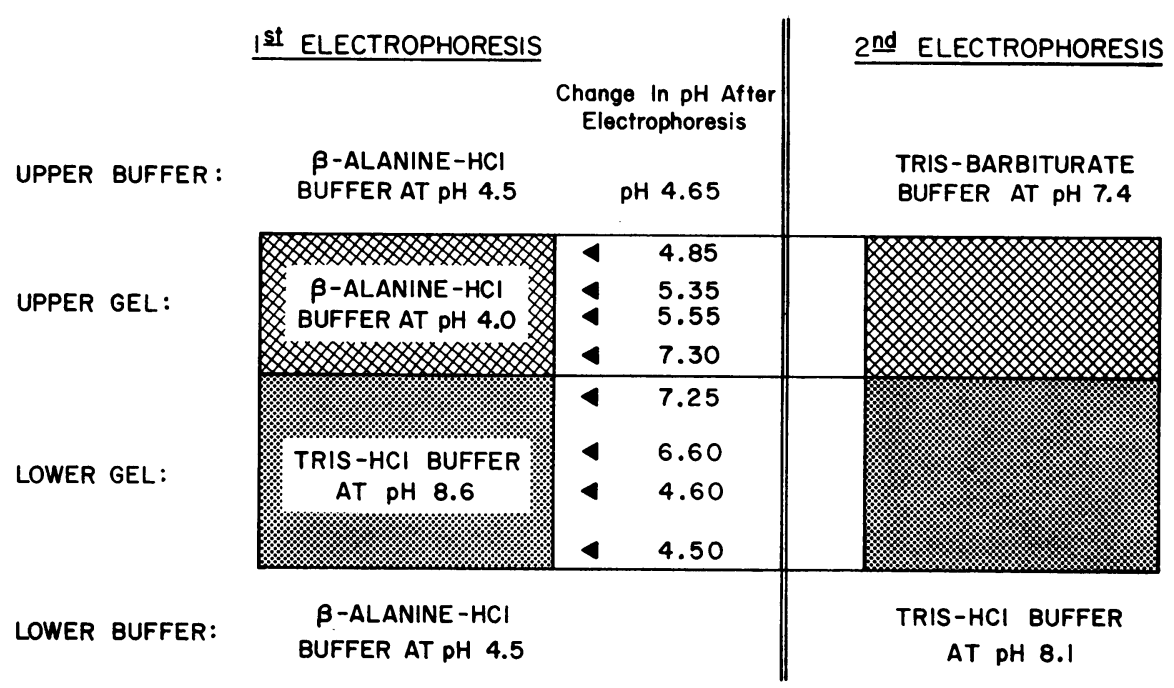

FIGURE 1 Double gel electrophoresis. Illustration of procedure of the two electrophoreses. The gel employed was $7.5 \%$ polyacrylamide.

liters of the second upper electrode buffer. Then, the upper buffer reservoir was filled with 2 liters of the second upper electrode buffer, and the second electrophoresis elution buffer was connected. The second electrophoresis was carried out at $50 \mathrm{ma}$ constant current for $18-20 \mathrm{hr}$. The rate of elution was $60 \mathrm{ml}$ per $\mathrm{hr}$, and the effluent was collected in $10-\mathrm{ml}$ fractions.

Preparative polyacrylamide electrophoresis. Preparative gel electrophoresis was performed by the method of Ornstein and Davis $(15,16)$ with slight modifications, using a Buchler Poly-Prep ${ }^{\circledR}$ apparatus (Buchler Instruments Inc., N. J.) The gel system consisted of a concentrating gel of $1.25 \%$ polyacrylamide in $0.059 \mathrm{M}$ Tris-phosphate at $\mathrm{pH} 7.2$ and a resolving gel of $7.5 \%$ polyacrylamide in $0.375 \mathrm{M}$ Tris- $\mathrm{HCl}$ at $\mathrm{pH}$ 8.9. The buffers employed were as follows: $0.052 \mathrm{M}$ Tris-0.052 м glycine at $\mathrm{pH} 8.9$ (upper buffer) ; $0.1 \mathrm{M}$ Tris- $\mathrm{HCl}$ at $\mathrm{pH} 8.1$ (lower and elution buffer); four times concentration of the lower buffer (membrane holder buffer). The protein sample from the previous step, not exceeding $50 \mathrm{mg}$ in $5 \mathrm{ml}$ of the upper electrode buffer containing $3 \%$ sucrose was applied, and was run at $50 \mathrm{ma}$ constant current for 15-17 hr. The rate of elution and the fraction size were the same as described in double gel electrophoresis procedure.

Paper electrophoresis. Reverse flow paper electrophoresis with a glycine acetate buffer at $\mathrm{pH} 8.6$ (17) was performed to determine the maximal binding capacities of TBG, using the Spinco-Durrum apparatus (Beckman Instruments, Inc., Palo Alto, Calif.), as described in detail elsewhere (18). The samples were diluted with $2 \%$ human serum albumin until the maximal binding capacity was approximately $21 \mu \mathrm{g}$ T4 per $100 \mathrm{ml}$. To the diluted preparations were added a tracer amount of $\mathrm{T} 4{ }^{181} \mathrm{I}$ and 75 $\mu \mathrm{g}$ of stable T4 per $100 \mathrm{ml}$. Samples of $8 \mu \mathrm{l}$ were applied 3.5 inches from the anodal end of each Whatman filter paper strip (grade 1, SP pattern) previously saturated with glycine acetate buffer at $\mathrm{pH}$ 8.6. Reverse flow electrophoresis was run for $19 \mathrm{hr}$ at $12 \mathrm{ma}$ constant current at room temperature. After electrophoresis, the paper strips were dried and scanned with a Nuclear-Chicago Actigraph III
(Model 1004, Nuclear-Chicago Corp., Des Plains, Ill.). The maximal binding capacities were calculated from per cent distribution of radioactivity relative to the amounts of T4 added. The maximal binding capacity of approximately $21 \mu \mathrm{g}$ per $100 \mathrm{ml}$ in normal human serum (18) corresponded to $3 \mu \mathrm{g}$ per $\mathrm{g}$ of serum protein because of a mean serum total protein concentration approximating $7 \mathrm{~g}$ per $100 \mathrm{ml}$. The starting material actually employed for the first step was Fraction IV-4 or IV -5,6 which was found to have 1.5 to 3 times the binding capacity of normal serum per gram protein.

Interaction between $\mathrm{TBG}$ and albumin and competitive binding of T4 between TBG and TBPA were studied using the paper electrophoresis procedure. A purified TBG preparation with a tracer amount of added $\mathrm{T}_{4-{ }^{131} \mathrm{I}}$ was diluted in glycine acetate buffer or in albumin solutions of various concentrations. Electrophoresis was performed in the same way as described above, followed by scanning for the distribution of radioactivity.

Binding affinity of TBG for T4 was determined by competitive binding of a tracer amount of $\mathrm{T} 4{ }^{-131} \mathrm{I}$ between purified TBG and purified TBPA $^{2}$ with known maximal binding capacity. The effect of added albumin on T4-binding affinity was also studied.

According to the law of mass action, the association constant $(K)$ of a T4-binding protein is expressed by the following equation $(1,4)$ :

$$
K_{\text {protein }}=\frac{(\text { Protein } \cdot \mathrm{T} 4)}{(\mathrm{F} \text { protein })(\mathrm{F} \mathrm{T} 4)}
$$

where $($ Protein $\cdot \mathrm{T} 4)=$ concentration of binding sites occupied by $\mathrm{T} 4$ on the particular protein; $(\mathrm{F}$ protein $)=$ concentration of unoccupied sites on the protein; $(\mathrm{F} T 4)=$ concentration of free $\mathrm{T} 4$. Therefore, the ratio of $K$ values

\footnotetext{
${ }^{2}$ The sample of purified TBPA was kindly supplied by Dr. Ulysses S. Seal.

${ }^{3}$ Hamaday, S., Y. Takemura, and K. Sterling. 1971. Immunochemical studies on serum lacking in thyroxine-binding globulin. J. Clin. Endocrinol. Metab. In Press.
} 
for two binding proteins can be calculated

$$
\begin{aligned}
& K_{\mathrm{TBG}} / K_{\mathrm{TBPA}}= \frac{(\mathrm{TBG} \cdot \mathrm{T} 4)}{(\mathrm{F} \mathrm{TBG})(\mathrm{F} \mathrm{T} 4)} / \frac{(\mathrm{TBPA} \cdot \mathrm{T} 4)}{(\mathrm{F} \mathrm{TBPA})(\mathrm{F} \mathrm{T} 4)} \\
&= \frac{(\mathrm{TBG} \cdot \mathrm{T} 4)}{(\text { total TBG })-(\mathrm{TBG} \cdot \mathrm{T} 4)} \\
& \times \frac{(\text { total TBPA })-(\mathrm{TBPA} \cdot \mathrm{T} 4)}{(\mathrm{TBPA} \cdot \mathrm{T} 4)}
\end{aligned}
$$

where $($ Protein $\cdot \mathrm{T} 4)=$ concentration of binding sites occuTBPA were calculated by addition of increasing amounts of stable T4 using reverse flow paper electrophoresis (17, 18).

Disc electrophoresis. Analytical disc gel electrophoresis was performed by the method of Ornstein and Davis described in references 15 and 16 . Histograms were made of the distribution of radioactivity, primarily by counting unstained gel sliced into $2-\mathrm{mm}$ sections. The distribution of stained protein bands of intact gels was used for reference to characterize radioactive peaks in histograms. In addition, histograms were also prepared of the radioactivity remaining after Amido black $10 \mathrm{~B}$ staining; these results generally afforded corroborative identification. In some preparations, the distribution and density of stained protein bands was determined with a Chromoscan ${ }^{\circledR}$ (Joyce-Loebl \& Co., Ltd., Gateshead-on-Tyne, England) equipped with an automatic integrator.

Immunoelectrophoresis. Immunoelectrophoresis was performed by the method of Scheidegger (19). The electrode buffer was diethylbarbiturate acetate buffer at $\mathrm{pH} 8.8, \mu=$ 0.05 , and gels were prepared with $1.5 \%$ agarose in $1: 3$ dilution of the same buffer. Antisera to TBG were obtained from guinea pigs hyperimmunized with a mixture of the preparations obtained after DEAE-Sephadex chromatography and an equal volume of complete Freund's adjuvant. Horse and goat antisera to human whole serum were obtained from Hyland Laboratories, Los Angeles, Calif., and from Behringwerke AG, Hoechst Pharmaceutical Co., Kansis City, Mo.

Analytical ultracentrifugation. Sedimentation velocity and equilibrium analyses were kindly performed by Drs. W. N. Poillon and P. Feigelson as described (20) in a Spinco model $\mathrm{E}$ analytical ultracentrifuge equipped with a photoelectric scanner and ultraviolet absorption optical system. The absorbance of the cell contents at $280 \mathrm{~m} \mu$ was determined at intervals as a function of distance from the center of rotation. Sedimentation velocity runs were carried out on purified TBG solutions of 1 and $3 \mathrm{mg}$ per $\mathrm{ml}$ in $0.1 \mathrm{M}$ sodium phosphate, $\mathrm{pH} 7.0$ at $20^{\circ} \mathrm{C}$ at a speed of 52,000 rpm. One experiment using a TBG solution of $11.2 \mathrm{mg}$ per $\mathrm{ml}$ was kindly carried out by Dr. K. Schmid to obtain schlieren patterns at a high concentration. Sedimentation coefficients were calculated for solutions of these protein concentrations in water at $20^{\circ} \mathrm{C}$. The molecular weight of TBG was determined by sedimentation equilibrium by the method of Yphantis (21). The conditions were similar to those for sedimentation velocity except that the runs were carried out for 18-24 hr at a speed of $36,000 \mathrm{rpm}$.

Amino acid analysis. The amino acid composition of TBG was kindly determined by Dr. R. E. Canfield, according to the method of Spackman, Stein, and Moore (22) as modified (23). The samples were hydrolyzed in $6 \mathrm{~N} \mathrm{HCl}$ at $110^{\circ} \mathrm{C}$ for periods ranging from 24 to $72 \mathrm{hr}$. Tryptophan content was determined separately by the method of Bencze and Schmid (24).
Carbohydrate analysis. The carbohydrate analysis of TBG was kindly performed by Dr. Roger W. Jeanloz by gasliquid chromatography (25) after methanolysis as well as after acid hydrolysis for $4 \mathrm{hr}$ with $2 \mathrm{~N} \mathrm{HCl}$.

\section{RESULTS}

\section{Purification of TBG}

TBG was purified from Cohn Fractions IV-5,6 and IV-4 of human serum. A summary of the methods is shown in Table $\mathrm{I}$.

The Cohn fractions in $0.075 \mathrm{~m}$ sodium acetate buffer at $\mathrm{pH} 5.0$ were labeled with a tracer amount of $\mathrm{T} 4-{ }^{125} \mathrm{I}$ $(0.18-0.36 \mu \mathrm{Ci}, 4-5 \mathrm{ng}$ of $\mathrm{T} 4$ per $100 \mathrm{ml}$ ) before purification. Thereafter, no $T 4{ }^{125} \mathrm{I}$ was added to avoid oversaturation of TBG.

$C M$-cellulose chromatography. The first step, an overflow phenomenon, carried out at $\mathrm{pH} 5.0$, allowed the CM-cellulose column to retain $95-97 \%$ of the protein of starting material, while $60-70 \%$ of the radioactivity ran through with the elution buffer. The radioactive peak with high specific activity was pooled and concentrated by ultrafiltration (with membrane Diaflo ${ }^{\circledR}$, UM-10, Amicon Corp., Lexington, Mass.). Maximal binding capacity of the pooled fraction was about $78 \mu \mathrm{g}$ $\mathrm{T} 4$, per $\mathrm{g}$ of protein, and analysis by disc electrophoresis indicated removal of substantial amounts of alpha and beta globulins.

Gel filtration on Sephadex G-200. The pooled, concentrated peaks obtained from 5 to $15 \mathrm{CM}$-cellulose columns were combined in a volume of $10-15 \mathrm{ml}(2-3 \mathrm{~g}$ protein per $100 \mathrm{ml}$ ), and after dialysis against $0.05 \mathrm{M}$ $\mathrm{NaCl}$, the solution was applied to the column of Sephadex G-200. The elution pattern of a typical experiment is shown in Fig. 2. Approximately $80 \%$ of the radioactivity and $20-25 \%$ of the protein applied were recovered in the TBG area. Maximal binding capacity of the pooled fraction was approximately $244 \mu \mathrm{g}$ T4 per g, and analysis by disc electrophoresis showed that most of alpha and beta globulins were removed, although a considerable amount of albumin was still present.

DEAE-Sephadex (A-50) chromatography. The pooled TBG preparation obtained by gel filtration was applied to a column of DEAE-Sephadex A-50. The elution pattern of a typical experiment (see Methods section for details) is shown in Fig. 3. TBG was eluted mainly from $0.15-0.18 \mathrm{~m}$ chloride at $\mathrm{pH} 8.0$. The major peak (tubes $55-80$ ) represented $50-55 \%$ of the radioactivity and $10 \%$ of the protein of the sample applied. The pooled major peak had a maximal TBG capacity of $1586 \mu \mathrm{g} \mathrm{T} 4$ per $\mathrm{g}$ and showed two bands in disc gel electrophoretic analysis (Fig. 4). In addition to the major peak there was, almost always, a small hump (tubes 81-95 of Fig. 3) which was not completely characterized owing to failure to obtain sufficient protein 


\begin{tabular}{|c|c|c|c|c|c|c|}
\hline & \multirow[b]{2}{*}{$\begin{array}{l}\text { Recovery of } \\
\text { protein }\end{array}$} & \multirow[b]{2}{*}{$\begin{array}{l}\text { Recovery of } \\
\text { radioactivity }\end{array}$} & \multirow[b]{2}{*}{$\begin{array}{l}\text { Purification } \\
\text { based on } \\
\text { radioactivity }\end{array}$} & \multirow[b]{2}{*}{$\begin{array}{l}\text { Specific } \\
\text { activity }\end{array}$} & \multicolumn{2}{|c|}{$\begin{array}{l}\text { Purification based on } \\
\text { specific activity }\end{array}$} \\
\hline & & & & & $\begin{array}{l}\text { With frac- } \\
\text { tion IV sub- } \\
\text { fraction } \equiv 1\end{array}$ & $\begin{array}{c}\text { With } \\
\text { serum } \equiv 1\end{array}$ \\
\hline Starting material & $\%$ & $\%$ & & $M B C^{*} / \mathrm{g}$ protein & & \\
\hline $\begin{array}{l}\text { Fraction IV-5,6 or } \\
\text { Fraction IV-4 }\end{array}$ & 100 & 100 & 1 & 6.92 & 1.0 & 2.3 \\
\hline $\begin{array}{l}\text { (1) Carboxymethyl (CM) cellulose } \\
\text { chromatography }\end{array}$ & 5 & 68 & 14 & 77.9 & 11.3 & 26 \\
\hline $\begin{array}{l}\text { (2) Gel Filtration on Sephadex } \\
\text { G-200 }\end{array}$ & 1.1 & 52 & 47 & 244 & 35.3 & 81 \\
\hline $\begin{array}{l}\text { (3) DEAE-Sephadex (A-50) } \\
\text { chromatography }\end{array}$ & 0.1 & 29 & 290 & 1,586 & 229 & 526 \\
\hline $\begin{array}{l}\text { (4) "Double gel" } \\
\text { electrophoresis }\end{array}$ & 0.015 & 17 & 1130 & 6,511 & 941 & 2170 \\
\hline $\begin{array}{l}\text { (5) Second DEAE-Sephadex } \\
\text { chromatography }\end{array}$ & 0.0057 & 13 & 2280 & $12,520 \ddagger$ & $1810 \ddagger$ & $4160 \ddagger$ \\
\hline $\begin{array}{l}\text { (6) Polyacrylamide } \\
\text { electrophoresis }\end{array}$ & 0.0041 & 9.4 & 2290 & 14,740 & 2130 & 4900 \\
\hline
\end{tabular}

* MBC signifies maximal binding capacity in $\mu \mathrm{g}$ T4.

$\ddagger$ These values were calculated using the recoveries of radioactivity and optical density.

material to date. Whether this hump was due to microheterogeneity of native TBG or denaturation in the course of handling, remains to be determined in the future.

"Double gel" electrophoresis. This procedure utilizes the negative charge TBG possesses at $\mathrm{pH} 4.5$ or below. An upper gel at $\mathrm{pH} 4.0$ was placed above a $\mathrm{pH} 8.6$ resolving gel, and two electrophoretic runs were carried out with different upper and lower buffers (Fig. 1).

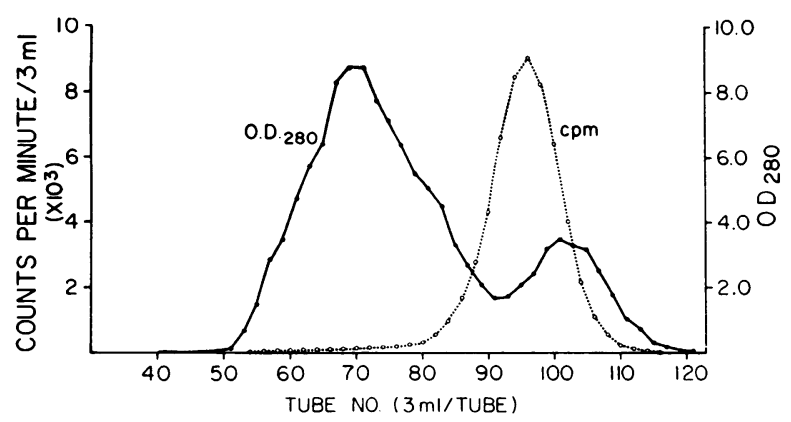

FIGURE 2 Gel filtration by Sephadex G-200. The radioactive peak (tubes 84-106) contained approximately $80 \%$ of the applied radioactivity but only $20-25 \%$ of the protein.
In the first run with an upper buffer of $\mathrm{pH} 4.5$, TBG had sufficient negative charge to enter the upper gel whereas most of the other proteins, including all the albumin, were excluded and recovered from the upper electrode buffer. The acidic buffer was then replaced by $\mathrm{pH} 7.4$ buffer, and electrophoresis resulted in a single major band of protein (Fig. 4). The TBG fraction obtained contained approximately $15 \%$ of the protein and $60 \%$ of the radioactivity of the total applied. Maxi-

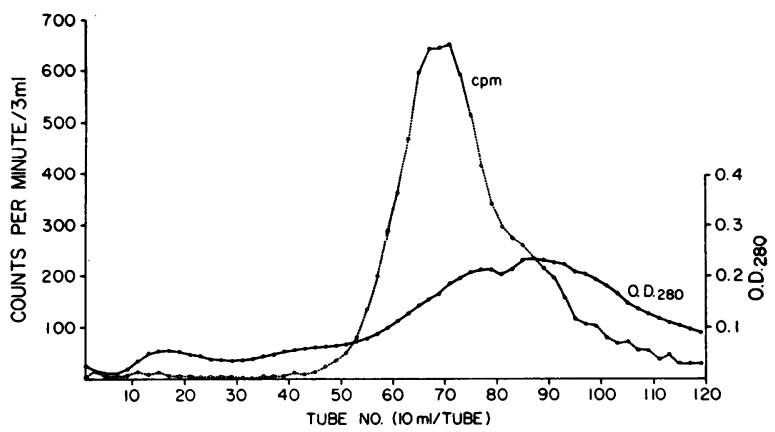

Figure 3 DEAE-Sephadex (A-50) chromatography. Additional protein without radioactivity remained on the column and could be eluted with buffer of higher ionic strength. 


\section{Origin}
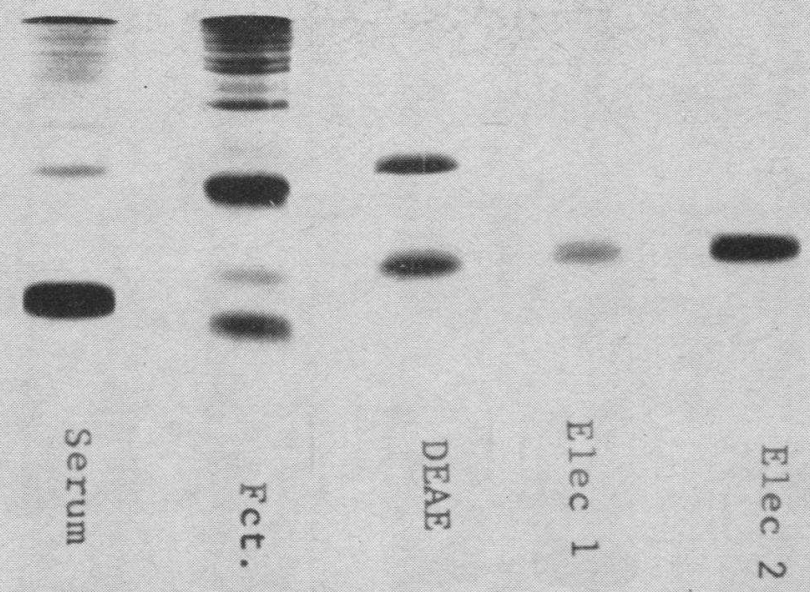

$$
\text { (x) }
$$

\section{Anode}

FigURE 4 Disc electrophoretic analysis (polyacrylamide gel). "Fct" signifies Fraction IV -4 and illustrates the large number of bands. "DEAE" shows a typical result after the DEAE-Sephadex step. The faster moving band (below) is not mainly composed of TBG, even though the mobility is similar to the visible TBG bands of "Elec. 1" and "Elec. 2," which signify, respectively, the results after the first ("double gel") electrophoresis and the second electrophoretic separation. The final product illustrates a distinct single band of protein. The direction of the anode was down.

mal binding capacity of the fraction was $6511 \mu \mathrm{g}$ T4 per $\mathrm{g}$, and disc electrophoretic analysis showed a single major band of protein (Fig. 4).

Second DEAE-Sephadex (A-50) chromatography. To obtain maximal purity, the TBG fraction obtained from double gel electrophoresis was occasionally subjected to rechromatography on a small column of DEAESephadex, employing a similar chloride gradient to that described in the Methods section. Approximately $76 \%$ of radioactivity and $38 \%$ OD applied was recovered in the TBG area.

Polyacrylamide gel electrophoresis. The final step of purification was preparative discontinuous polyacrylamide electrophoresis. The elution pattern of a typical experiment is shown in Fig. 5. Approximately $72 \%$ of radioactivity and $72 \% \mathrm{OD}$ applied were recovered in TBG area. The major portion of the TBG exhibited constant specific activity, suggesting homogeneity of the preparation obtained (Fig. 5). The leading and trailing edges of the peak were added to a subsequent preparation from double gel electrophoresis, and reelectrophoresed to recover some additional TBG. Maximal binding capacity of the purified TBG was $14,740 \mu \mathrm{g}$ T4 per $\mathrm{g}$ and disc electrophoretic analysis indicated a distinct single band of protein (Fig. 4).

As suggested by the tubes depicted in Fig. 4, a stained TBG band could be visualized readily after the initial (double gel) electrophoresis. This is not the same as the stained band after the initial step of DEAE-Sephadex which was produced principally by inert components as evident from the specific activity (Table I).

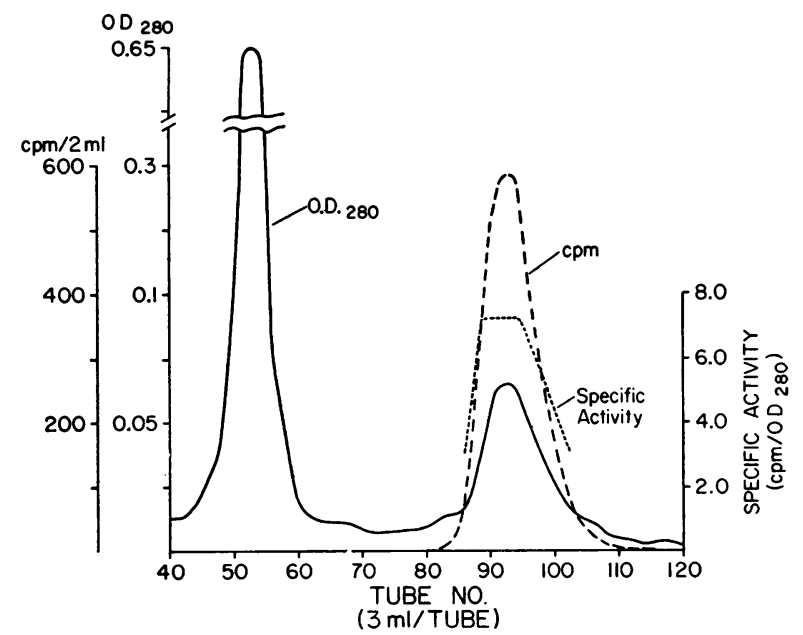

FIgURE 5 Polyacrylamide electrophoresis. The constant specific activity across the TBG protein peak is illustrated. The first big peak represented by tubes $45-60$ is not due to protein but rather to riboflavin added to the concentrating gel, as shown by its absorption spectrum. Approximately $70 \%$ of the optical density due to protein was present in the TBG area. 


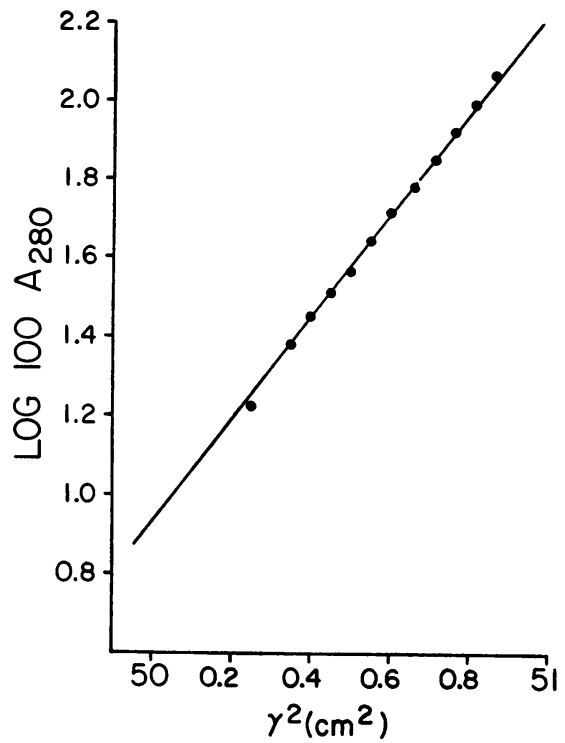

FIgURE 6 Sedimentation equilibrium of purified TBG illustrating linear relationship between $\log y$ and $r^{2}$.

On conventional paper electrophoresis at $\mathrm{pH} 8.6$ in the glycine acetate system, partially purified TBG was clearly evident in a stained band of protein. Despite the appearance of a single TBG band in Fig. 4, careful visual inspection invariably revealed additional extremely faint bands which cannot be seen in the figure. It was for this reason that a second polyacrylamide gel electrophoresis was necessary, and, in addition, the second DEAE-Sephadex chromatography was advisable. Only after the final electrophoretic procedure was it possible to obtain a single TBG band without the other faint bands noted above. Under these circumstances visual identification of a single TBG band was corroborated by the finding of more than $98 \%$ of stained protein

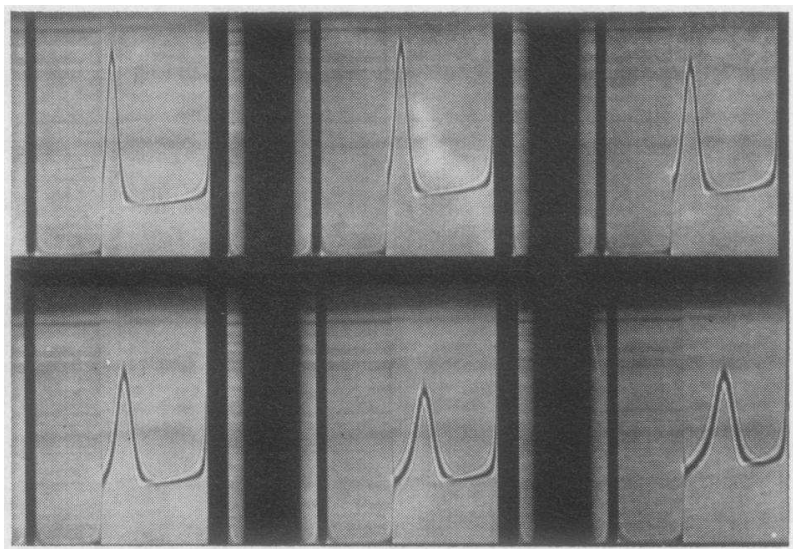

FIGURE 7 Sedimentation velocity patterns of TBG. The speed was $56,000 \mathrm{rpm}$; temperature $20^{\circ} \mathrm{C}$; the six patterns illustrated are from photographs taken after 18, 26, 34, 42, 58 , and $74 \mathrm{~min}$ of centrifugation. in this band on determination of density by Chromoscan ${ }^{\circledR}$.

Sedimentation analyses. Sedimentation equilibrium demonstrated a linear relationship between $\log y$ and $r^{2}$ (Fig. 6), indicating homogeneity of the protein.

Four determinations of molecular weight were carried out at different protein concentrations with the following results :

$\begin{array}{lll}0.02 & \mathrm{mg} / \mathrm{ml} & 39,200 \\ 0.1 & \mathrm{mg} / \mathrm{ml} & 35,150 \\ 0.6 & \mathrm{mg} / \mathrm{ml} & 39,800 \\ 1.0 & \mathrm{mg} / \mathrm{ml} & 31,930\end{array}$

The mean molecular weight was $36,520 \pm 3692$ (sD), and was considered to approximate 36,500 . The assumed partial specific volume of 0.73 was employed for the calculation.

Sedimentation velocity runs provided compatible findings. The sedimentation patterns obtained at a concentration of $11.2 \mathrm{mg}$ per $\mathrm{ml}$ are shown in Fig. 7. A single symmetrical peak was obtained for purified TBG. The sedimentation coefficient, $s_{20, w}$, was $3.0 \times 10^{-13}$ assuming partial specific volume of 0.73 . Additional sedimentation velocity runs yielded sedimentation coefficients of 2.99 , 3.23 , and $2.65 \mathrm{~S}$, or a mean of $3.0 \pm 0.24$ (SD). No concentration dependence was discernible in sedimentation behavior. Therefore, no attempt was made to extrapolate calculated values of $s_{v_{0}, w}$ to infinite dilution, and the mean value of $3.0 \mathrm{~S}$ was considered equivalent to that at infinite dilution, i.e. $s^{\circ}{ }_{20, v}$.

Physical and chemical characteristics of TBG. The purified TBG appeared homogeneous according to preparative and analytical disc electrophoresis, immunoelectrophoresis, sedimentation velocity and sedimentation equilibrium runs. The molecular characteristics are listed in Table II.

The diffusion constant $\left(D_{20, w}\right)$ and Stokes Radius (a) were computed from the sedimentation constant $\left(s_{20, w}\right)$ and mean molecular weight, $M_{\text {equ 11, given in }}$ Table II. The extinction coefficient $\left(E_{1 \mathrm{~cm}}^{1 \%}\right.$ at $\left.280 \mathrm{~m} \mu\right)$ of 7.25 was obtained from determination of the absorbance at $280 \mathrm{~m} \mu$ of several weighed samples of $1 \mathrm{y}$ -

TABLE II

Molecular Characteristics of $T B G$

\begin{tabular}{ll}
\hline$s_{20, w}$ & $3.0 \times 10^{-13} \mathrm{sec}$ \\
$D_{20, w}$ & $7.39 \times 10^{-7} \mathrm{~cm}^{2} / \mathrm{sec}$ \\
$M_{\text {equil }}$ & 36,500 \\
Stokes radius, $a$ & $2.88 \times 10^{-7} \mathrm{~cm}$ \\
Frictional ratio, $f / f \circ$ & 1.31 \\
Binding constants & $\mathrm{n}=1, \mathrm{k} \sim 10^{10}$ \\
$E_{1 \mathrm{~cm}}^{1 \%}$ at $280 \mathrm{~m} \mu$ & 7.25 \\
Absorbance $280 / 260 \mathrm{~m} \mu$ & 1.35 \\
Isoelectric point & $\mathrm{pH} \mathrm{3.8}$ \\
\hline
\end{tabular}




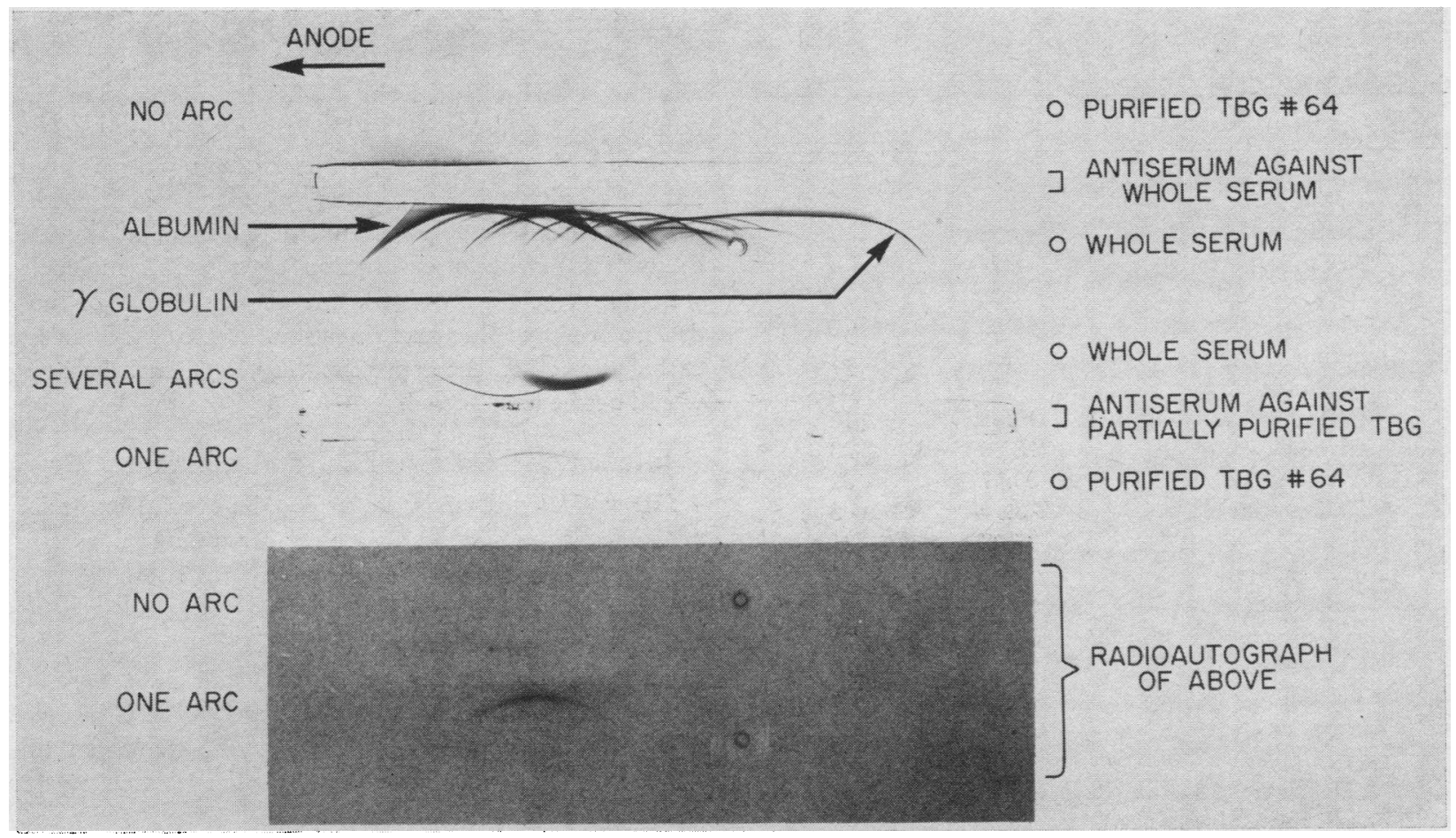

FIGURE 8 Immunoelectrophoresis of TBG. The upper portion of the figure illustrates the lack of any arc when purified TBG \#64 was run with antiserum against whole serum which produced the usual large number of arcs with whole serum. In contrast, antiserum against partially purified TBG (after DEAE-Sephadex chromatography) yielded several arcs with whole serum but only a single arc with purified TBG \#64. T4- ${ }^{181} \mathrm{I}$ had been added to all the protein solutions studied and radioautographs were made. The radioautograph below illustrates darkening due to radioactivity in the single TBG arc only, confirming the identification as TBG.

ophilized TBG which had been dried for at least 18 $\mathrm{hr}$ in a desiccator over $\mathrm{P}_{2} \mathrm{O}_{5}$.

The isoelectric point given represents the best information available from the direction of migration on paper at low $\mathrm{pH}$. At $\mathrm{pH} 4.0$, TBG moved toward the anode, but it migrated toward the cathode at $\mathrm{pH}$ below 3.7. In the range of $\mathrm{pH} 3.7-3.9$ the protein remained at the origin or had very slight mobility. More definitive investigation by isoelectric focus has not as yet been carried out, but the estimated isoelectric point of 3.8 was considered correct to within the nearest 0.1 unit. Such a value would be compatible with the behavior during double gel electrophoresis in that TBG entered the upper gel which contained beta alanine- $\mathrm{HCl}$ buffer at $\mathrm{pH} 4.0$, whereas most of the remaining serum proteins were excluded from this gel, and appeared in the supernatant fluid which exhibited foaming at the end of the first step.

Immunoelectrophoretic studies. Immunoelectrophoresis of purified TBG also provided evidence for homogeneity of the preparation. Thus purified TBG showed a single precipitation arc in a position between alpha 1 and alpha 2 globulins (Fig. 8). Radioautography of the preparation demonstrated that the precipitation arc was precisely superimposable upon the darkened area containing $\mathrm{T} 4-^{181} \mathrm{I}$ bound to TBG (Fig. 8). Therefore, it was concluded that the single precipitin arc contained TBG itself.

Amino acid analysis. The amino acid composition of the purified TBG is shown in Table III. Tryptophan content was determined separately by the method of Bencze and Schmid (24). The results differed somewhat from the previous reports (7-9).

Carbohydrate analysis. Carbohydrate analyses performed after methanolysis and after acid hydrolysis gave results (Table IV) differing from previous reports $(7,8)$. The carbohydrate content approximates $15 \%$ by weight.

Gel filtration studies on purified TBG. The molecular weight obtained for TBG was 36,500, differing considerably from previous results (7-9). The discrepancy raised a question as to whether the TBG obtained might be a subunit of the molecule as it exists in serum. Gel filtration studies on Sephadex G-200 demonstrated that 
TABLE III

Amino Acid Composition of $T B G$

\begin{tabular}{|c|c|c|}
\hline \multicolumn{2}{|c|}{ Preparation 55} & \multirow[t]{2}{*}{ Residues* } \\
\hline & $10^{-2} \mu$ moles & \\
\hline Lysine & 28.52 & 18 \\
\hline Histidine & 10.82 & 7 \\
\hline Arginine & 8.0 & 4 \\
\hline Aspartic acid & 37.35 & 26 \\
\hline Threonine & 25.83 & 20 \\
\hline Serine & 27.00 & 24 \\
\hline Glutamic acid & 46.84 & 30 \\
\hline Proline & 19.68 & 16 \\
\hline Glycine & 18.56 & 23 \\
\hline Alanine & 30.57 & 32 \\
\hline Half cystine & 3.99 & 3 \\
\hline Valine & 25.98 & 21 \\
\hline Methionine & 9.68 & 6 \\
\hline Isoleucine & 16.22 & 12 \\
\hline Leucine & 38.31 & 28 \\
\hline Norleucine & 0 & 0 \\
\hline Tyrosine & 8.63 & 4 \\
\hline Phenylalanine & 21.03 & 12 \\
\hline Tryptophan & $\ddagger$ & 3 \\
\hline \multicolumn{2}{|c|}{ Number of residues } & 289 \\
\hline \multicolumn{2}{|c|}{ Amino acid molecular weight } & 30,713 \\
\hline \multicolumn{2}{|c|}{ Carbohydrate molecular weight } & 5,178 \\
\hline \multicolumn{2}{|c|}{ Total molecular weight } & 35,891 \\
\hline
\end{tabular}

* Calculated for amino acid molecular weight approximating 31,000 (of total molecular weight approximating 36,000 ). $\ddagger$ Determined separately by spectrophotometry (24).

the purified TBG showed the same elution volume as that of native TBG in serum, apparently excluding this possibility (Fig. 9).

TABLE IV

Carbohydrate analysis of $T B G$

\begin{tabular}{lcr}
\hline & \multicolumn{1}{c}{ Residues* $^{*}$} \\
\hline Fucose & g per 100 g & \\
Xylose & 0 & 0 \\
Mannose & 0.5 & 1 \\
Galactose & 2.3 & 5 \\
Glucose & 2.5 & 6 \\
Glucosamine & 0.8 & 2 \\
Galactosamine & 5.0 & 11 \\
Sialic acid & 0 & 0 \\
Number of residues & 3.7 & 4 \\
Carbohydrate molecular weight & 5,178 \\
Amino acid molecular weight & 30,713 \\
Total molecular weight & 35,891
\end{tabular}

* Calculated from carbohydrate molecular weight approximating $15 \%$ of total molecular weight approximating 36,000 .
The radioactive peak in the top panel of Fig. 9 emerged slightly ahead of the optical density peak of albumin, which would signify a higher molecular weight than that of albumin if TBG were a carbohydrate-free "typical" globular protein. However, the atypical behavior of glycoproteins during gel filtration on Sephadex G-200 columns has been studied in detail by Andrews (26) with a description of apparent molecular weights on gel filtration considerably in excess of those determined by ultracentrifugation. Since TBG has a carbohydrate content approximating $15 \%$, such behavior would not be unexpected.

\section{Interaction between TBG and albumin}

Paper electrophoresis of purified TBG with and without added albumin. Studies by reverse flow paper electrophoresis suggested the possibility of interaction between TBG and albumin (Fig. 10). For reference, the radioactive scan of normal serum is shown with TBG in its usual position between alpha 1 and alpha 2 globulins. A preparation of partially purified TBG showed a slightly but significantly faster mobility. When this was diluted $1: 3$ with buffer, the mobility became greater than that of albumin. At this dilution, with protein concentration of $56 \mu \mathrm{g}$ per $\mathrm{ml}$, the maximal binding capacity was $25 \mu \mathrm{g}$ T4 per $100 \mathrm{ml}$, slightly above that of normal serum. This diluted preparation with an added equimolar amount of albumin showed the same mobility as that of TBG in serum. The result raised the possibility of interaction between TBG and albumin.

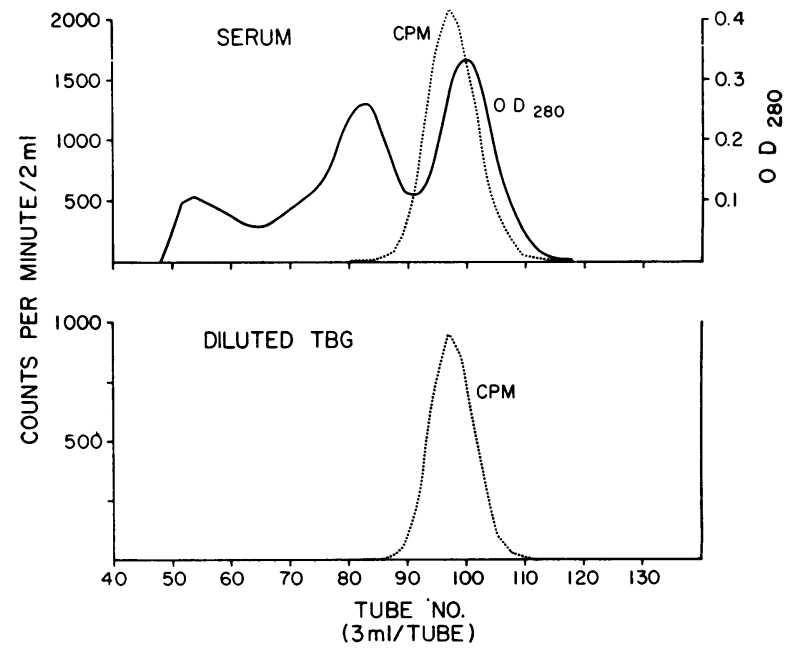

Figure 9 Gel filtration by Sephadex G-200. The method employed was the same as that previously described for the second step of the protein fractionation procedure except that $5 \mathrm{ml}$ of serum or TBG solution enriched with T4- ${ }^{125} \mathrm{I}$ was applied to the column and potassium phosphate buffer, $\mathrm{pH} 7.4$, was used for elution. The radioactive peak of diluted TBG has the same elution volume as that of native TBG in serum. 


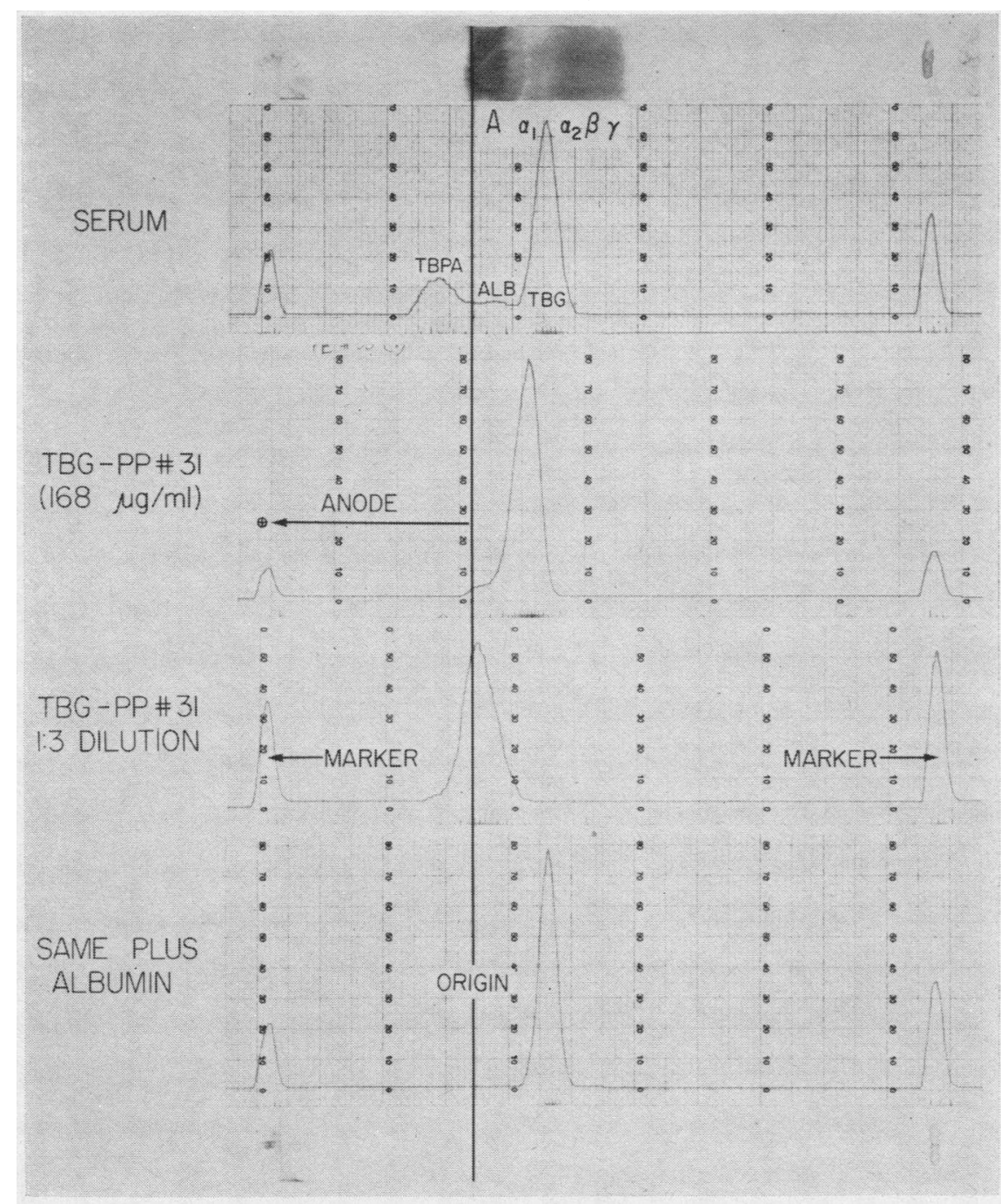

FIGURE 10 Reverse flow paper electrophoresis. Radioactive scans aligned with paper strips with markers at top and bottom of illustration. The serum above is included for reference of the interalpha position of TBG. The slightly faster mobility of Preparation \#31 of TBG is illustrated as well as the further increase in mobility upon dilution with buffer. The addition of an equimolar amount of albumin restored the mobility to that of TBG in serum.

Estimation of association constant of TBG for T4 with and without added albumin. Thyroxine-binding affinity was estimated by competition using pure TBPA with and without added albumin (Fig. 11). With the addition of albumin, the association constant of the purified TBG for T4 was 50.9 times that of TBPA and was estimated to be $1.17 \times 10^{10} \mathrm{M}^{-1}$ if $2.3 \times 10^{8} \mathrm{M}^{-1}$ (2, 4) was taken as the association constant of TBPA for T4. However, the value would be $8.1 \times 10^{8} \mathrm{~m}^{-1}$ if $1.6 \times$ $10^{7} \mathrm{M}^{-1}$ (27), which was obtained from purified TBPA, was employed for the calculation. In the absence of albumin, the binding affinity of TBG appeared to increase 2-3 times that of the TBG preparation containing al- bumin, despite the same maximal binding capacity. Therefore, it was inferred that T4-binding affinity of TBG may be affected by protein-protein interactions.

For present purposes, it appears reasonable to consider that the association constant is of the order of $10^{\circ}-10^{10}$, pending the performance of equilibrium dialysis studies when sufficient purified protein is available.

The maximal binding capacity of purified TBG was $14,740 \mu \mathrm{g}$ per $\mathrm{g}$ of protein or approximately $15,000 \mu \mathrm{g}$ per $\mathrm{g}$ which represented more than a 2100 -fold purification of the starting material or about 5000 times that of serum. From this information, it is possible to 
TBG BINDING IN PRESENCE

AND ABSENCE OF ALBUMIN

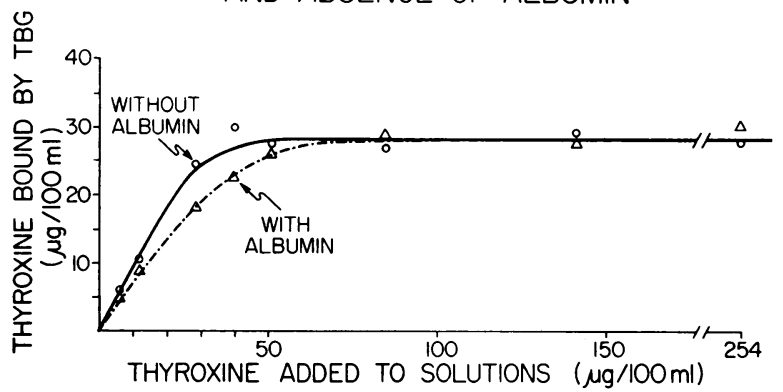

FIGURE 11 Competitive binding of thyroxine between TBG and purified TBPA in the presence and absence of albumin. Despite the same maximal binding capacity, greater binding by TBG is indicated in the absence of albumin at lower thyroxine additions. Prealbumin with a maximal binding capacity of $296 \mu \mathrm{g} / 100 \mathrm{ml}$ was present in all tubes to serve as a competitor.

make a calculation of the number of binding sites per molecule of TBG. The observed maximal binding capacity of $15,000 \mu \mathrm{g}$ per $\mathrm{g}$ of protein may be expressed in terms of moles employing the known molecular weight of thyroxine (777) and our presently estimated molecular weight for TBG $(36,500)$. The quotient

$$
\frac{15,000}{777}=19.3 \mu \text { moles }
$$

while the quotient

$$
\frac{1,000,000}{36,500}=27.4 \mu \text { moles. }
$$

Therefore, the observed maximal binding capacity would be equivalent to the quotient $19.3 / 27.4$ or 0.7 molecules of the ligand thyroxine per molecule of TBG. The interpretation offered, as discussed below, is that TBG possesses a single T4-binding site per protein molecule.

If the binding capacity of the average normal serum approximates $21 \mu \mathrm{g}$ thyroxine per $100 \mathrm{ml}$ serum (18) it would therefore follow (on the assumption of a single T4-binding site per molecule of circulating TBG) that the concentration of TBG in normal human serum approximates $1 \mathrm{mg}$ per $100 \mathrm{ml}$.

Loss of binding affinity of $T B G$. Dilute solutions of purified TBG in water or in buffer solution tended to develop a small precipitate incapable of binding added T4- ${ }^{125} \mathrm{I}$. The clear supernatant fluid after centrifugation showed some loss of binding affinity. The same phenomenon, ascribed to denaturation, was observed in much less degree after thawing of frozen concentrated solutions of the pure protein. Minimal losses were observed with months of storage in the dry state in a desiccator at $4^{\circ} \mathrm{C}$ when dry amorphous powder was obtained by lyophilization of the protein in water. Re- moval of the T4 ligand from TBG preparations by Sephadex or ion exchange resins resulted in loss of TBG capacity.

\section{DISCUSSION}

It was previously demonstrated by electrophoresis at $\mathrm{pH} 4.5$ that TBG had a slow mobility toward the anode, suggesting an isoelectric point of approximately $\mathrm{pH} 4$ (10). The negative charge which TBG possesses at $\mathrm{pH}$ below 4.5, permitted development of new procedures for separation. CM-cellulose chromatography at $\mathrm{pH}$ 5.0 proved to be a simple and effective method for removing most proteins other than acidic proteins. Further, double-gel electrophoresis employing a $\mathrm{pH} 4.0$ upper gel together with a $\mathrm{pH} 4.5$ buffer allowed acid glycoproteins only to enter the gel. Electrophoresis at $\mathrm{pH} 4.5(5,10)$ also suggested that TBG was probably in the more rapidly moving portion of $\mathrm{M}-2$ proteins of Mehl, Golden, and Winzler (28). The $\mathrm{pH}$ gradient which arose within the gel could accelerate the movement of TBG into the gel (Fig. 1), and the second electrophoresis using alkaline buffers made it possible to elute TBG in 18-20 $\mathrm{hr}$ with possible separation from other M-2 proteins. No albumin was demonstrated in the preparation obtained by this method.

The TBG preparation described in the present report had a calculated maximal binding capacity of 0.7 mole of $\mathrm{T} 4$ per mole of protein. This value, approaching unity, was viewed as suggestive of a single major binding site. The estimated association constant of $10^{10}$ for the single site would be entirely consonant with previous reported studies of whole serum $(1,2,4,30)$. As mentioned earlier, definitive determination of the binding constants of this protein must await availability of larger supplies which would permit binding studies by equilibrium dialysis. The discrepancy between 0.7 and unity appeared greater than the analytical errors of the methods. Consideration was given to the possibility that this difference could be ascribed to the endogenous T4 ordinarily present in human serum which normally has approximately one-third of the available binding sites for T4 occupied $(1,30)$. Such an interpretation, however plausible, was not supported by butanol-extractable iodine (BEI) values determined by the Boston Medical Laboratory which signified insufficient endogenous hormone to account fully for the discrepancy. Although the removal of the T4 ligand from TBG preparations by means of Sephadex or ion exchange resins was studied during the course of the present work, such procedures evidently resulted in losses of TBG due to denaturation. Therefore, such work has been deferred for the present. The possibility must, of course, be entertained that even the best TBG preparations available have suffered some loss of binding affinity without the evident precipitation 
referred to in the last item of Results. Subtle alteration in the conformation of a glycoprotein molecule could conceivably result in a loss of ability to bind its ligand.

In the present work, the concentrations of TBG were assayed by measuring maximal T4-binding capacities with reverse flow paper electrophoresis, inasmuch as recovery of radioactivity does not represent precisely recovery of $T B G$, but rather that of radioactive $T 4$. Although $\mathrm{T} 4$ is rather tightly bound by serum T4-binding proteins, it seems that the bound $\mathrm{T} 4$ is redistributed or transferred from one binding protein to another during chromatography. DEAE-cellulose chromatography of human serum indicated that almost all the radioactive T4 was bound by TBG, and very little of the labeled T4 applied was bound by albumin and TBPA (31). Further, gel filtration on Sephadex G-200 demonstrated a single radioactive peak of TBG in human serum. Because $80-85 \%$ of the radioactivity was recovered in the TBG area, it was probable that some portion of the radioactive thyroxine dissociated from albumin and TBPA and was bound by TBG during gel filtration. Therefore, determination of maximal binding capacity is considered a more accurate TBG assay than recovery of radioactivity. However, it is interesting that the extent of purification based upon maximal binding capacity did not differ significantly from that based upon radioactivity, since each was approximately 2100 times the starting material in Table I. On other occasions, however, there were appreciable losses of radioactivity in comparison with binding capacity.

The final TBG preparation obtained by the present method had $s_{20, x}$ of $3.0 \mathrm{~S}$ and a molecular weight of 36,500. This molecular weight is considerably smaller than those obtained by Seal and Doe (7) and by Giorgio and Tabachnick (8). Seal and Doe (7) reported that a slow sedimenting material was present and increased in relative amounts with dilution of the TBG preparation, suggesting a dissociation of the protein. However, no dissociation was reported in the TBG preparation of Giorgio and Tabachnick (8). The present TBG demonstrated no concentration-dependent behavior at concentrations ranging from $0.02 \mathrm{mg}$ to 11.2 $\mathrm{mg}$ per $\mathrm{ml}$ in ultracentrifugal studies. In view of the findings on ultracentrifugation and the gel filtration studies shown in Fig. 9, the possibilities of dissociation or polymerization of the protein appear unlikely.

The brief report of Seal and Doe (7) gave a sedimentation coefficient of $3.6 \mathrm{~S}$ and an estimated molecular weight of 59,000. Recently, Giorgio and Tabachnick (8) reported that the sedimentation constant of their TBG preparation was $3.92 \mathrm{~S}$ and the molecular weight was estimated to be 58,000 . The amino acid and carbohydrate compositions were, however, considerably different from those of Seal and Doe (7). The smaller molecular weight in the present report raised the ques- tion of whether our purified TBG could be a subunit. This suggestion is not supported by the results of gel filtration on Sephadex G-200 which demonstrated that the purified TBG emerged at the same position as the native TBG in serum (Fig. 9).

Tata (6) described a partially purified TBG preparation which had $s_{20, w}$ of $3.5 \mathrm{~S}$ and a molecular weight of 40,000 to 50,000. Ingbar, Dowling, and Freinkel (5) also reported a partially purified TBG preparation, which had $s_{20, \text { w }}$ of $4.1 \mathrm{~S}$. On the other hand, Petermann, Robbins, and Hamilton estimated from ultracentrifugal studies of whole serum labeled with $\mathrm{T} 4-{ }^{131} \mathrm{I}$, that the sedimentation coefficient, $s_{20, x}$, was $3.3 \mathrm{~S}$ (29) and the molecular weight would be about 50,000 although it could range from 30,000 to $1,000,000$, depending on the molecular shape $(30)$. The present findings of $s_{20, w}$ of $3.0 \mathrm{~S}$ and molecular weight of 36,500 would seem to be a quite satisfactory agreement with those of Petermann, Robbins, and Hamilton (29).

Recently, Marshall and Pensky (9) reported relatively simply procedures using two column chromatographies on DEAE-cellulose and DEAE-Sephadex to obtain a TBG preparation $\left(s_{20, w}, 3.91\right.$; mol wt, 54,000) which was probably similar to that of Giorgio and Tabachnick (8) $\left(s_{20, w}, 3.92 ; \mathrm{mol} \mathrm{wt}, 58,000\right)$. It is entirely possible that these preparations contained considerable amounts of inert material. This is our presumption since we have been unable to obtain very high maximal binding capacities of TBG with two DEAESephadex fractionations alone.

The final TBG preparation obtained in the present work showed a constant specific activity in preparative disc gel electrophoresis (Fig. 4), indicating homogeneity. Further evidence of homogeneity was provided by the single band on analytical disc electrophoresis as well as the single arc on immunoelectrophoresis. The findings illustrated in Fig. 8 revealed the failure of the appearance of any precipitin arc when a purified TBG was run with antiserum against whole serum, owing to insufficient anti-TBG antibodies in such an antiserum. Conversely, although several arcs were observed with whole serum run with antiserum against partially purified TBG, none of these arcs corresponded precisely to the actual TBG precipitin arc, seen with the purified preparation and confirmed by its correspondence with the arc on radioautography. The failure of appearance of such an arc from whole serum was ascribed to the low concentration of TBG in normal human serum, estimated to approximate $1.0 \mathrm{mg}$ per $100 \mathrm{ml}$. In other work reported separately (32), a visible precipitin line was readily produced by double immunodiffusion (Ouchterlony) employing larger amounts of normal serum and antiserum in each well.

The studies suggesting an interaction between TBG and human serum albumin illustrated in Figs. 10 and 
11 are regarded as suggestive rather than conclusive evidence. The slightly faster mobility of a dilute TBG preparation was increased still further upon threefold dilution with buffer, but the mobility was restored to that of $T B G$ in serum upon addition of an equimolar amount of albumin. The possible artefact of adsorption of purified TBG to the paper, especially at low concentration, could conceivably give a false indication of "faster" electrophoretic mobility under the circumstances of the reverse flow electrophoretic method. However, the possibility of such an artefact was considered less likely than the occurrence of a proteinprotein interaction. When a diluted TBG solution was kept for prolonged periods, particularly in the liquid state, an increasing amount of fast moving TBG was formed, and this could not be changed to TBG of normal mobility by the addition of albumin. Moreover, the glycine acetate system used in these studies tends to minimize adhesion to paper. Further suggestions of a protein-protein interaction are provided by the findings illustrated in Fig. 11, as well as the recent report from this laboratory concerning the behavior of TBG during starch gel electrophoresis (32). An additional instance of an interaction between a thyroxine binding protein and another protein molecule is provided in the recent work of Kanai, Raz, and Goodman, illustrating the interaction between prealbumin (TBPA) and retinolbinding protein to form a complex in a molar ratio of $1: 1(27,33)$.

Nevertheless, during ultracentrifugation and gel filtration, there was no evident association of TBG with another protein molecule. At present, it would be premature to draw conclusions until more definitive work can be done concerning the conformation and binding properties of TBG in the presence and absence of albumin.

Recently, Dr. W. Wardle Fullerton, working in the laboratory of Professor Barbara W. Low at Columbia University, has grown crystals of our TBG from aqueous alcoholic solution at $\mathrm{pH}$ 8. After the solution had been standing at room temperature for 4 days the crystals, approximately $30 \mu$ long, were observed. This has raised the possibility of obtaining further information about the structure of this protein by X-ray crystallography, which should be facilitated by the four iodine atoms possessed by the ligand, thyroxine.

\section{ACKNOWLEDGMENTS}

The authors wish to express their thanks to Mr. Lewis $\mathrm{H}$. Larsen for generously providing protein fractions as starting material; Drs. William N. Poillon, Philip Feigelson, Karl Schmid for ultracentrifugal studies; Dr. Robert E. Canfield for amino acid analyses; Dr. Roger W. Jeanloz for carbohydrate analyses; Dr. Wladyslaw J. Manski for Chromoscan of analytical disc gel electrophoresis; Dr. D. Grün- berger for assistance in preparation of fraction IV-4 from fraction IV; and Dr. J. L. Oncley for advice and guidance throughout the course of the work.

This work was supported in part by Grant AM-10739 from the U. S. Public Health Service, and Grant P-461 from the American Cancer Society.

\section{REFERENCES}

1. Robbins, J., and J. E. Rall. 1960. Proteins associated with the thyroid hormones. Physiol. Rev. 40: 415.

2. Woeber, K. A., and S. H. Ingbar. 1968. The contribution of thyroxine-binding prealbumin to the binding of thyroxine in human serum, as assessed by immunoadsorption. J. Clin. Invest. 47: 1710.

3. Lutz, J. H., and R. I. Gregerman. 1969. pH Dependence of the binding of thyroxine to prealbumin in human serum. J. Clin. Endocrinol. Metab. 29: 487.

4. Hamada, S., T. Nakagawa, T. Mori, and K. Torizuka. 1970. Re-evaluation of thyroxine binding and free thyroxine in human serum by paper electrophoresis and equilibrium dialysis, and a new free thyroxine index. J. Clin. Endocrinol. Metab. 31: 166.

5. Ingbar, S. H., J. T. Dowling, and N. Freinkel. 1957. The purification of thyroxine-binding protein by ion-exchange resins. Endocrinology. 61: 321 .

6. Tata, J. R. 1961. The purification of thyroxine-binding globulin and thyroxine-binding prealbumin. Clin. Chim. Acta. 6: 819 .

7. Seal, U. S., and R. P. Doe. In Proceedings of the Second International Congress of Endocrinology August 1968, Excerpta Medica Foundation, 1965 June. London. 325.

8. Giorgio, N. A., Jr., and M. Tabachnick. 1968. Thyroxineprotein interactions $\mathrm{V}$. Isolation and characterization of a thyroxine-binding globulin from human plasma. J. Biol. Chem. 243: 2247.

9. Marshall, J. S., and J. Pensky. 1969. Studies on human thyroxine-binding globulin (TBG) I. Purification of TBG and immunologic studies on the relationship between TBG from normal persons and those with TBG deficiency. J. Clin. Invest. 48: 508 .

10. Robbins, J., M. L. Petermann, and J. E. Rall. 1955. Electrophoresis of the thyroxine-binding protein of serum at $\mathrm{pH}$ 4.5. J. Biol. Chem. 212: 403.

11. Sterling, K., D. Bellabarba, E. S. Newman, and M. A. Brenner. 1969. Determination of triiodothyronine concentration in human serum. J. Clin. Invest. 48: 1150.

12. Braverman, L. E., S. H. Ingbar, and K. Sterling. 1970. Conversion of thyroxine (T4) to triiodothyronine (T3) in athyreotic human subjects. J. Clin. Invest. 49: 855.

13. Hughes, W. L. 1954. Interstitial Proteins: The proteins of blood plasma and lymph. In The Proteins. H. Neurath and K. Bailey, editors. Academic Press Inc., New York 2 (Pt. B) : 663.

14. Porath, J., and H. Bennich, 1962. Recycling chromatography. Arch. Biochem. Biophys. 98 (Suppl. 1) : 152.

15. Ornstein, L. 1964. Disc electrophoresis-I. Background and theory. Ann. N. Y. Acad. Sci. 121: 321.

16. Raymond, S. 1964. Acrylamide gel electrophoresis. Ann. N. Y. Acad. Sci. 121: 350 .

17. Sterling, K., and M. Tabachnick. 1961. Paper electrophoretic demonstration of thyroxine-binding prealbumin fraction in serum. Endocrinology. 68: 1073.

18. Inada, M., and K. Sterling. 1967. Thyroxine transport in thyrotoxicosis and hypothyroidism. J. Clin. Invest. 46: 1442. 
19. Scheidegger, J. J. 1955. Une micro-méthode de l'immunoélectrophorese. Int. Arch. Allergy Appl. Immunol. 7: 103.

20. Poillon, W. N., H. Maeno, K. Koike, and P. Feigelson. 1969. Tryptophan oxygenase of pseudomonas acidovorans. Purification, composition and subunit structure. J. Biol. Chem. 244 : 3447.

21. Yphantis, D. A. 1964. Equilibrium ultracentrifugation of dilute solutions. Biochemistry. 3: 297.

22. Spackman, D. H., W. H. Stein, and S. Moore. 1958. Automatic recording apparatus for use in the chromatography of amino acids. Anal. Chem. 30: 1190.

23. Spackman, D. H. 1963. Accelerated system for the automatic analysis of amino acids. Fed. Proc. 22: 244.

24. Bencze, W. L., and K. Schmid. 1957. Determination of tyrosine and tryptophan in proteins. Anal. Chem. 29: 1193.

25. Katzman, R. L., A. K. Bhattacharyya, and R. W. Jeanloz. 1969. Invertebrate connective tissue. I. The amino acid and carbohydrate composition of the collagen from Thyone briareus. Biochim. Biophys. Acta. 184: 523.

26. Andrews, P. 1965. The gel-filtration behaviour of proteins related to their molecular weights over a wide range. Biochem. J. 96: 595.

27. Raz, A., and D. S. Goodman. 1969. The interaction of thyroxine with human plasma prealbumin and with the prealbumin-retinol binding protein complex. J. Biol. Chem. 244: 3230.

28. Mehl, J. W., F. Golden, and R. J. Winzler. 1949. Mucoproteins of human plasma. IV. Electrophoretic demonstration of mucoproteins in serum at $\mathrm{pH}$ 4.5. Proc. Soc. Exp. Biol. Med. 72: 110.

29. Petermann, M. L., J. Robbins and M. G. Hamilton. 1954. Sedimentation of the thyroxine-binding protein of serum in the partition cell. J. Biol. Chem. 208: 369.

30. Robbins, J., and J. E. Rall. 1957. The interaction of thyroid hormones and protein in biological fluids. Rec. Progr. Horm. Res. 13: 161.

31. Fahey, J. L., P. F. McCoy, and M. Goulian. 1958. Chromatography of serum proteins in normal and pathologic sera. The distribution of protein bound carbohydrate and cholesterol, siderophilin, thyroxin-binding protein, B12 binding protein, alkaline and acid phosphatases, radioiodinated albumin and myeloma proteins. J. Clin. Invest. $37: 272$.

32. Inada, M., and K. Sterling. 1970. Interconvertibility of two different moieties of thyroxine binding alpha-globulin on starch gel electrophoresis. J. Clin. Endocrinol. Metab. 31: 417.

33. Kanai, M., A. Raz, and D. S. Goodman. 1968. Retinolbinding protein: The transport protein for vitamin $\mathrm{A}$ in human plasma. J. Clin. Invest. 47: 2025. 